\title{
Amphibians found in the Amazonian Savanna of the Rio Curiaú Environmental Protection Area in Amapá, Brazil
}

\author{
Janaina Reis Ferreira Lima ${ }^{1,2}$, Jucivaldo Dias Lima ${ }^{1,2}$, Soraia Dias Lima², Raullyan Borja Lima Silva ${ }^{2} \&$ \\ Gilda Vasconcellos de Andrade ${ }^{3}$ \\ ${ }^{1}$ Universidade Federal do Amazonas, Universidade Federal do Amapá, Rede BIONORTE, Programa de \\ Pós-graduação em Biodiversidade e Biotecnologia, Macapá, AP, Brazil \\ ${ }^{2}$ Instituto de Pesquisas Científicas e Tecnológicas do Estado do Amapá, Macapá, Amapá, Brazil \\ ${ }^{3}$ Universidade Federal do Maranhão, Departamento de Biologia, São Luís, MA, Brazil \\ *Corresponding author: Janaina Reis Ferreira Lima, e-mail: janareis@yahoo.com
}

LIMA, J. R. F., LIMA, J. D., LIMA, S. D., SILVA, R. B. L., ANDRADE, G. V. Amphibians found in the Amazonian Savanna of the Rio Curiaú Environmental Protection Area in Amapá, Brazil. Biota Neotropica. 17(2): e20160252. http://dx.doi.org/10.1590/1676-0611-BN-2016-0252

\begin{abstract}
Amphibian research has grown steadily in recent years in the Amazon region, especially in the Brazilian states of Amazonas, Pará, Rondônia, and Amapá, and neighboring areas of the Guiana Shield. Even so, few data are available for the Amazonian savannas of Brazil. To contribute to the understanding of the diversity of the amphibians of these savannas, we surveyed 15 temporary ponds, six located in open areas, seven on the edge of savanna forest, and two within the forest, in the savanna of the Rio Curiaú Environmental Protection Area (EPA) in Macapá, in the state of Amapá, northern Brazil. Sampling occurred from May 2013 to August 2014 during periods when the ponds contained water. Amphibians were sampled through visual and auditory surveys conducted during both the day- and the nighttime periods on seven days each month over a total of 84 days. A total of 1574 individuals belonging to four families, 12 genera, and 28 species were recorded during the surveys. The cumulative species curve reached the asymptote, indicating that sampling effort was adequate. The number of species was $25 \%$ higher than that reported in other studies in Amazonian savannas. Twelve species were recorded for the first time in the savanna of Amapá. Lysapsus boliviana was the most common species $(n=332$ of the individuals recorded). The greatest amphibian species richness found in the Rio Curiaú EPA was associated with the savanna mosaic, forest patches, lowland swamp, and temporary ponds. The results of this study contribute to the understanding of the diversity of amphibian species in the Guianan area of endemism in northern Brazil, and also the Amazonian savannas.
\end{abstract}

Keywords: Amphibians, Amazonian, Amapá, Savanna, savanna forest, species list.

\section{Anfíbios em Savana Amazônica na Área de Proteção Ambiental do Rio Curiaú, Amapá, Brasil}

Resumo: Existe um crescimento constante em estudos sobre os anfíbios Amazônicos especialmente nas regiões do Amazonas, Pará, Rondônia, Amapá e outras áreas no Escudo das Guianas. Porém, poucos estudos são realizados em Savana Amazônica no Brasil. Para diminuir esta lacuna, amostramos anfíbios em 15 lagoas temporárias, sendo seis em área aberta, sete com a borda próxima a mata de savana e 2 com borda interna em contato com a mata de savana na Área de Proteção Ambiental (APA) do Rio Curiaú em Macapá no estado do Amapá, norte do Brasil. As amostragens ocorreram de maio de 2013 a agosto de 2014, nos períodos em que as lagoas continham água, sete dias por mês, totalizando 84 dias de amostragem, através de procura visual e auditiva no período diurno e noturno. Os 1574 indivíduos registrados pertenciam a quatro famílias, 12 gêneros e 28 espécies. A curva de acumulação de espécies atingiu a assíntota, indicando que o esforço amostral foi suficiente. O número de espécies foi $25 \%$ maior que o registrado nos outros estudos em Savanas Amazônicas. Doze espécies foram registradas pela primeira vez em Savana Amapaense. Lysapsus boliviana contribuiu com o maior número de indivíduos $(\mathrm{n}=332)$. A maior riqueza de anfíbios nesta savana foi associada ao mosaico de savana, ilhas de matas de savana, florestas de várzea e lagoas temporárias existentes na APA do Curiaú. Os dados apresentados contribuem para preencher a lacuna de conhecimento para o Centro de Endemismo Guiana no norte do Brasil e em Savana Amazônica.

Palavras-chave: Anfíbios, Amazônia, Amapá, Savana, mata de savana, lista de espécies. 


\section{Introduction}

A total of 1080 amphibian species are currently known to occur in Brazil (Segalla et al. 2016), of which, 308 anurans, 18 caecilians, and five caudatans are found in Amazonia (Hoogmoed 2016a, b, Hoogmoed \& Galatti 2016). Studies of the diversity, geographic distribution, and ecology of Amazonian amphibians have increased considerably over the past decade, especially in the Brazilian Amazon basin. These studies have provided a great deal of valuable data, especially for the Brazilian states of Amazonas (Zimmerman \& Rodrigues 1990, Tocher et al. 2001, Gordo 2003, Neckel-Oliveira \& Gordo 2004, Vogt et al. 2007, Menin et al. 2008, Ilha \& Dixo 2010, Lima et al. 2012, Prudente et al. 2013, Waldez et al. 2013), Pará (Ribeiro-Junior et al. 2008, Avila-Pires et al. 2010), Rondônia (Bernarde 2007, Turci \& Bernarde 2008), and Amapá (Lima 2008, Queiroz et al. 2011, Araujo \& Costa-Campos 2014), as well as the countries of the Guiana Shield (Hoogmoed \& Avila-Pires 1991, Lescure \& Marty 2000, MacCulloch \& Reynolds 2012, Reynolds \& MacCulloch 2012, Cole et al. 2013).

Despite these advances, very few data are available on the amphibians of the Amazonian savannas of Brazil. In the state of Pará, Ávila-Pires et al. (2010) compiled a list of the amphibian species of the Grão-Pará Ecological Station, which encompasses both terra firme forests and savannas. Neckel-Oliveira et al. (2000) analyzed the distribution and diversity of amphibians in a savanna area at Alter do Chão, Pará state. Other savanna studies include that of Barbosa et al. (2007), who conducted an inventory in Roraima, and two recent studies that focused on the amphibian community of Amapá (Pereira-Junior et al. 2013, Costa-Campos 2015).

The savanna of Amapá is considered to be the most recent formation of the Amazonian savannas, and the most similar to those of the Cerrado of the ancient crystalline formations of the central Brazilian plateau (see Costa-Campos 2015). However, Silva et al. (2013) concluded that, while the arboreal stratum of this savana is composed of typical savanna plant species, the vegetation of the herbaceous-shrubby stratum is influenced by the anthropogenic impacts that are widespread in the region. The Amazonian savannas expanded through the region during the Cenozoic (Costa-Campos 2015), and are characterized by complex and heterogeneous phytophysiognomies influenced by the vegetation of neighboring biomes, accentuated by anthropogenic impacts (Sugai et al. 2014, Bitar et al. 2015).

Given this, inventories in areas of Amazonian savanna, such as that found in the Rio Curiaú Environmental Protection Area (EPA) are essential for the understanding of the formation of these environments, and the fauna that occupy them. In the specific case of this EPA, the heterogeneity of the habitats found around the ponds surveyed appears to be highly favorable to amphibian diversity (Souza \& Eterovick 2011, Fahr \& Kalko 2011).

Another important aspect of the biogeography of Amapá is that it is located in the Guianan area of endemism (Silva et al. 2005). Avila-Pires et al. (2010) emphasized the need to inventory this area due to the many new species found in the neighboring region of northern Pará, including the expansion of the known ranges of many species in this state and Brazil as a whole.

The savanna is the second most extensive landscape in Amapá, and is the dominant vegetation in the Rio Curiaú EPA, with a total area of 9861.92 ha. Data from the Amapá State Environment Secretariat (SEMA 2003) show that the most common anthropogenic pressures in this environment are burn-off for cassava (Manihot esculenta Crantz) plantations and the renovation of pasture for livestock, as well as squatting on private landholdings. In this context, the present study inventoried the amphibian fauna of the Amazonian savanna found in a conservation unit under anthropogenic pressure, with the aim of providing guidelines for the conservation of amphibians in this EPA, and in the Guianan area of endemism as a whole.

\section{Material and Methods}

\section{Study area}

The Rio Curiaú Environmental Protection Area (established through State Law No. 431 of August 15th, 1998, $0^{\circ} 10^{\prime} 0^{\prime \prime} \mathrm{N}$ and 51 ${ }^{\circ} 2^{\prime} 0^{\prime \prime} \mathrm{W}$ ) is located north of the municipality of Macapá, Amapá, and encompasses approximately 21,676 hectares (Figure 1). Lowland marshes and swamps (várzeas) are the predominant environments in the EPA, although approximately $35 \%$ of the area is covered in savanna (SEMA, 2003).

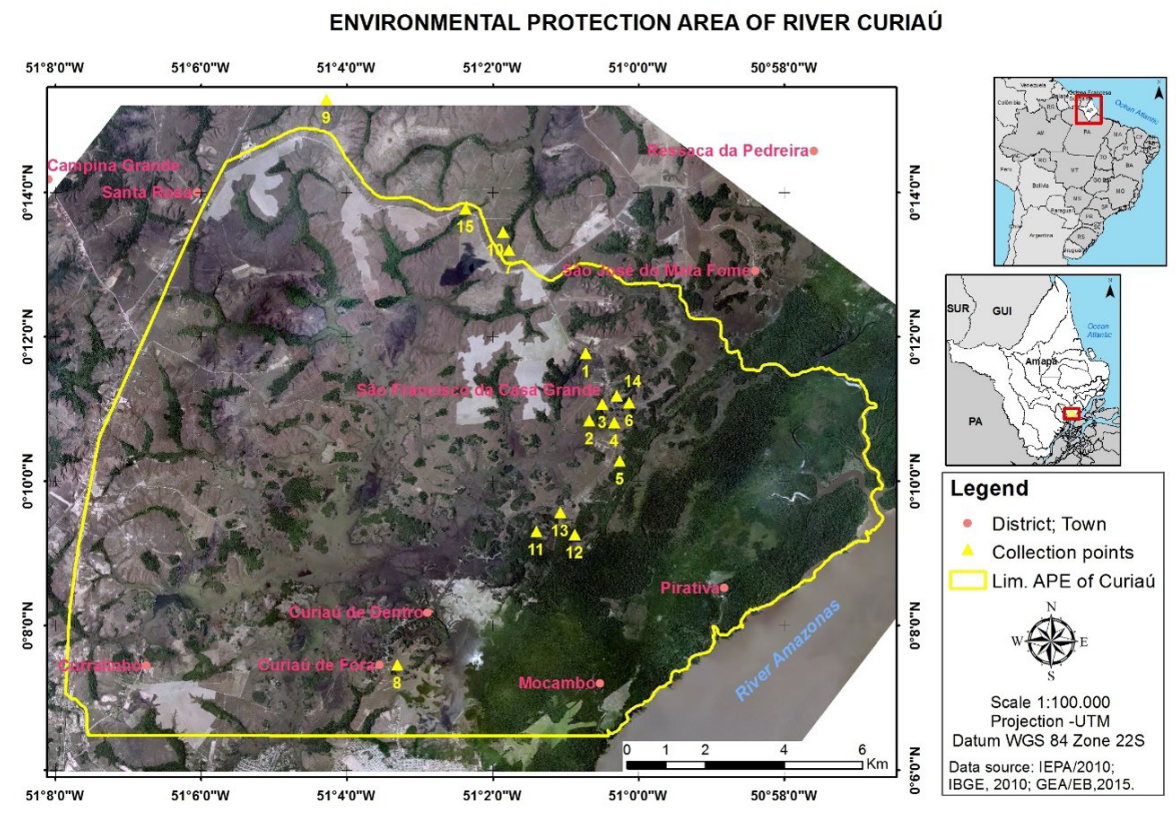

Figure 1. Location of the 15 ponds sampled in the Amazonian savanna of the Rio Curiaú Environmental Protection Area (including the surrounding area) in Amapá, northern Brazil. 
According to the Köppen classification, the predominant climate in the EPA is Tropical savanna (Aw, Peel et al. 2007). The rainy season usually lasts from January to June and is characterized by high precipitation (2500 mm, Silva et al. 2013). Average monthly temperature range from $24.4^{\circ} \mathrm{C}$ to $28.4^{\circ} \mathrm{C}$ (Costa-Campos 2015).

\section{Data collection}

A total of 15 temporary ponds, six of which were located in open areas, seven at the edge of the forest, and two within the savanna forest (Figure 2) were sampled between May and September 2013 and in February to August 2014. Data were collected by two researchers on seven days per month, for a total sample of 84 field days, during both the daytime (09:00-15:00 $\mathrm{h})$ and at night (18:00-00:00 h). The sampling period lasted until the complete drying of these temporary aquatic environments. All of the temporary ponds occupied by breeding anurans in the Rio Curiaú EPA were sampled, although small ponds (with an area of less than $100 \mathrm{~m}^{2}$ ) that lasted less than 15 days were excluded from the analyses due to time constraints. The amphibian species present at each site were recorded during visual and auditory surveys (Heyer et al. 1994). Searches were conducted in the different types of habitat and microhabitat found within each area.
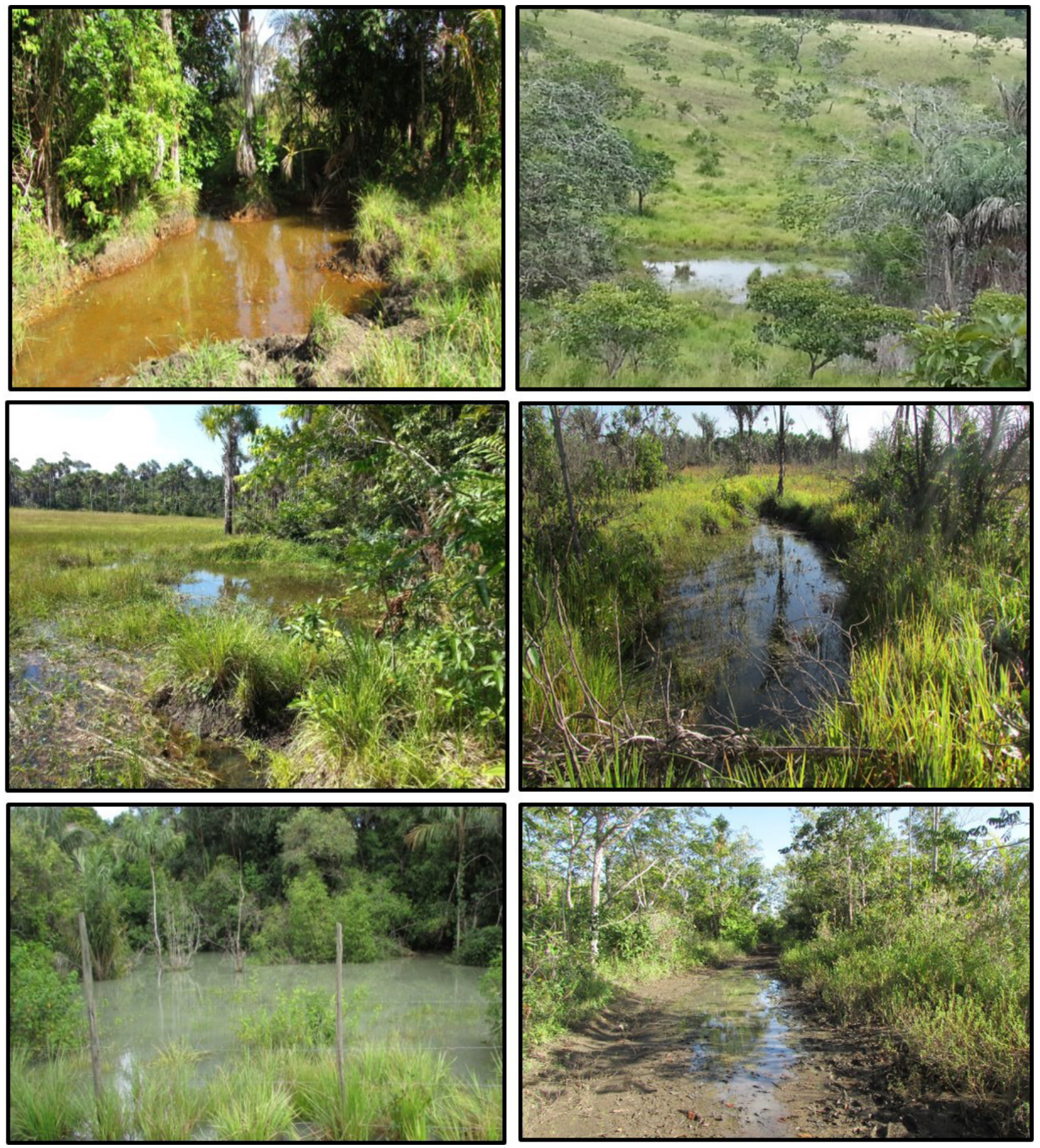

Figure 2. An example of the diversity of environments found in the temporary ponds sampled in the Amazonian savanna between May 2013 and August 2014 in the Rio Curiaú Environmental Protection Area in Amapá, northern Brazil. 
The voucher specimens were deposited in the Collection of the Fauna of Amapá at the Amapá State Institute for Scientific and Technological Research (IEPA, Appendix 1). Sampling was authorized by the Chico Mendes Institute for Biodiversity Conservation (SISBIO permit 38641-4/2014).

The amphibian species richness was determined by the total number of species recorded during the 12 months of sampling. The Chao 2 and Jackknife 2 estimators of species richness were also applied to the data. The Chao 2 is the most appropriate for relatively small samples, such as that of the present study ( $\mathrm{n}=12$ months), while Jackknife 2 is less conservative (Magurran, 2004). The analyses were run in EstimateS, version 9.1 (Colwell 2013).

\section{Results and Discussion}

A total of 1574 individuals belonging to four families, 12 genera, and 28 species were recorded in the study (Table 1, Figures 3-6). The cumulative species richness curve (Figure 7) reached the asymptote. However, the number of species observed (28) was lower than that estimated by Chao 2

Table 1. Amphibians recorded in temporary ponds in the Amazonian savanna of the Rio Curiaú Environmental Protection Area in Amapá, northern Brazil, between May 2013 and August 2014.

\begin{tabular}{|c|c|c|}
\hline Family & $\begin{array}{c}\text { Total } \\
\text { number of } \\
\text { individuals }\end{array}$ & $\begin{array}{c}\text { First record } \\
\text { in Amapá } \\
\text { savanna }\end{array}$ \\
\hline \multicolumn{3}{|l|}{ Bufonidae } \\
\hline Rhinella granulosa (Spix, 1824) & 114 & \\
\hline Rhinella marina (Linnaeus, 1758) & 11 & \\
\hline \multicolumn{3}{|l|}{ Hylidae } \\
\hline Dendropsophus nanus (Boulenger, 1889) & 95 & $\mathrm{X}$ \\
\hline Dendropsophus sp & 63 & $\mathrm{X}$ \\
\hline Hypsiboas boans (Linnaeus, 1758) & 6 & $\mathrm{X}$ \\
\hline Hypsiboas geographicus (Spix, 1824) & 7 & \\
\hline Hypsiboas multifasciatus (Günther, 1859"1858") & 70 & \\
\hline Hypsiboas punctatus (Schneider, 1799) & 81 & \\
\hline Hypsiboas raniceps Cope, 1862 & 12 & \\
\hline Lysapsus boliviana Gallardo, 1961 & 332 & \\
\hline Osteocephalus taurinus Steindachner, 1862 & 3 & \\
\hline Phyllomedusa hypochondrialis (Daudin, 1800) & 8 & \\
\hline Pseudis paradoxa (Linnaeus, 1758) & 23 & \\
\hline Scinax boesemani (Goin, 1966) & 27 & $\mathrm{X}$ \\
\hline Scinax fuscomarginatus (A. Lutz, 1925) & 31 & \\
\hline Scinax garbei (Miranda-Ribeiro, 1926) & 69 & $\mathrm{X}$ \\
\hline Scinax nebulosus (Spix, 1824) & 91 & \\
\hline Scinax ruber (Laurenti, 1768) & 65 & \\
\hline Sphaenorhynchus carneus (Cope, 1868) & 16 & \\
\hline Sphaenorhynchus lacteus (Daudin, 1800) & 19 & $\mathrm{X}$ \\
\hline \multicolumn{3}{|l|}{ Leptodactylidae } \\
\hline Hydrolaetare schmidti (Cochran \& Goin, 1959) & 5 & $\mathrm{X}$ \\
\hline Leptodactylus fuscus (Schneider, 1799) & 15 & \\
\hline Leptodactylus longirostris Boulenger, 1882 & 98 & $\mathrm{X}$ \\
\hline $\begin{array}{l}\text { Leptodactylus macrosternum Miranda-Ribeiro, } \\
1926\end{array}$ & 22 & \\
\hline Leptodactylus mystaceus (Spix, 1824) & 14 & $\mathrm{X}$ \\
\hline Leptodactylus petersii (Steindachner, 1864) & 15 & $\mathrm{X}$ \\
\hline Pseudopaludicola $\mathrm{sp}$ & 259 & $\mathrm{X}$ \\
\hline \multicolumn{3}{|l|}{ Microhylidae } \\
\hline Hamptophryne boliviana (Parker, 1927) & 3 & $\mathrm{X}$ \\
\hline TOTAL & 1574 & 12 \\
\hline
\end{tabular}

(29.96 \pm 2.3 species) and Jackknife 2 (33.96 \pm 3.1 species). A similar pattern was observed by Gondim-Silva et al. (2016) in a study of anurans in the Brazilian state of Bahia.

The number of amphibian species recorded in the Rio Curiaú EPA was $33 \%$ greater than that reported in other studies in Amazonian savannas. Barbosa et al. (2007) recorded 20 species in Roraima, for example, while Pereira-Junior et al. (2013) found the same number in an area of secondary forest surrounded by savanna and successional habitat on the campus of the Federal University of Amapá. Costa-Campos (2015) recorded 21 species in an area of savanna surrounded by experimental plantations on the grounds of the EMBRAPA campus in Amapá, while Neckel-Oliveira et al (2000) found 19 species on the margins of the Tapajós River and adjacent lakes, in Pará.

The family Hylidae was represented by the largest number of species (18), followed by the Leptodactylidae (7), Bufonidae (2), and Microhylidae (1). The predominance of the former two families is typical of the Amazon region and other South America biomes (Duelman 1988, Strussmann 2000, Gordo 2003, Neckel-Oliveira \& Gordo 2004, Ilha \& Dixo 2010 , Lima et al. 2012, Waldez et al. 2013).

Lysapsus boliviana (Figure 3F), a semi-aquatic anuran that lives on floating vegetation (Brandão et al. 2003, Furtado, et al. 2013), was the most abundant species ( $\mathrm{n}=332$ individuals). This species was previously recorded at a high density ( $\mathrm{n}=1240$ individuals $)$ in a temporary pond in the Rio Curiaú EPA (Furtado et al. 2014).

Twelve of the 28 species recorded in the Rio Curiaú EPA were recorded for the first time in the savannas of Amapá (Table 1). However, two of these species - Leptodactylus mystaceus and Leptodactylus petersii-are widespread in the terra firme forests of the Amazon basin (Lima 2008, Menin et al. 2008, Avila-Pires et al. 2010, Waldez et al. 2013, Lima et al. 2015). Similarly, Hypsiboas boans, Scinax boesemani, Hydrolaetare schmidit, and Hamptophryne boliviana were recorded by Lima (2008) in

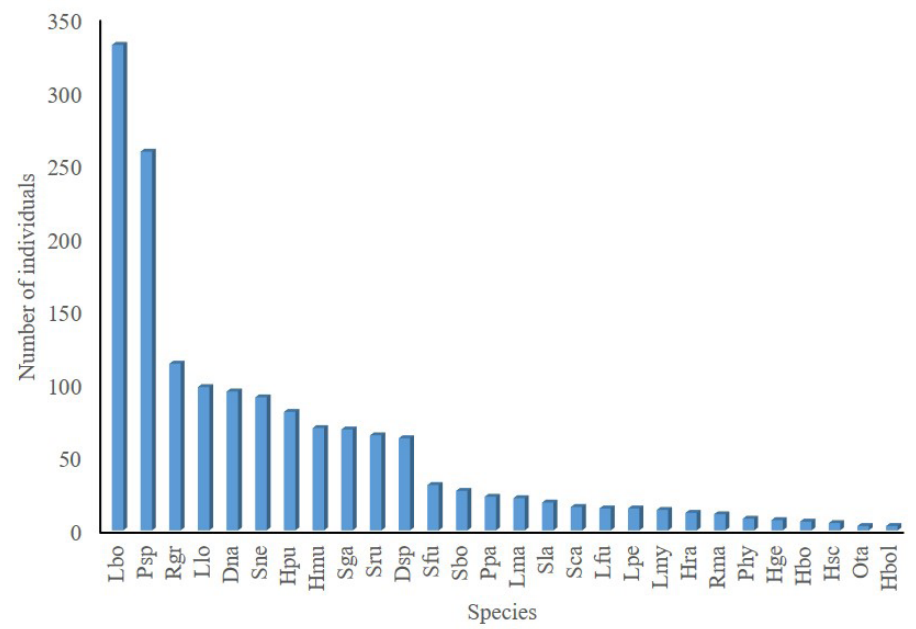

Figure 3. Abundance of the amphibian species recorded in the Amazonian savanna of the Rio Curiaú Environmental Protection Area in Amapá, northern Brazil. Lbo: Lysapsus boliviana, Psp: Pseudopaludicola sp., Rgr: Rhinella granulosa, Llo: Leptodactylus longirostris, Dna: Dendropsophus nanus, Sne: Scinax nebulosus, Hpu: Hypsiboas punctatus, Hmu: Hypsiboas multifasciatus, Sga: Scinax garbei, Sru: Scinax ruber, Dsp: Dendropsophus sp., Sfu: Scinax fuscomarginatus, Sbo: Scinax boesemani, Ppa: Pseudis paradoxa, Lma: Leptodactylus macrosternum, Sla: Sphaenorhyncus lacteus, Sca: Sphaenorhyncus carneus, Lfu: Leptodactylus fuscus, Lpe: Leptodactylus petersii, Lmy: Leptodactylus mystaceus, Hra: Hypsiboas raniceps, Rma: Rhinella marina, Phy: Phyllomedusa hypochondrialis, Hge: Hypsiboas geographicus, Hbo: Hypsiboas boans, Hsc: Hydrolaetare schmidti, Ota: Osteocephalus taurinus e Hbol: Hamptophryne boliviana. 

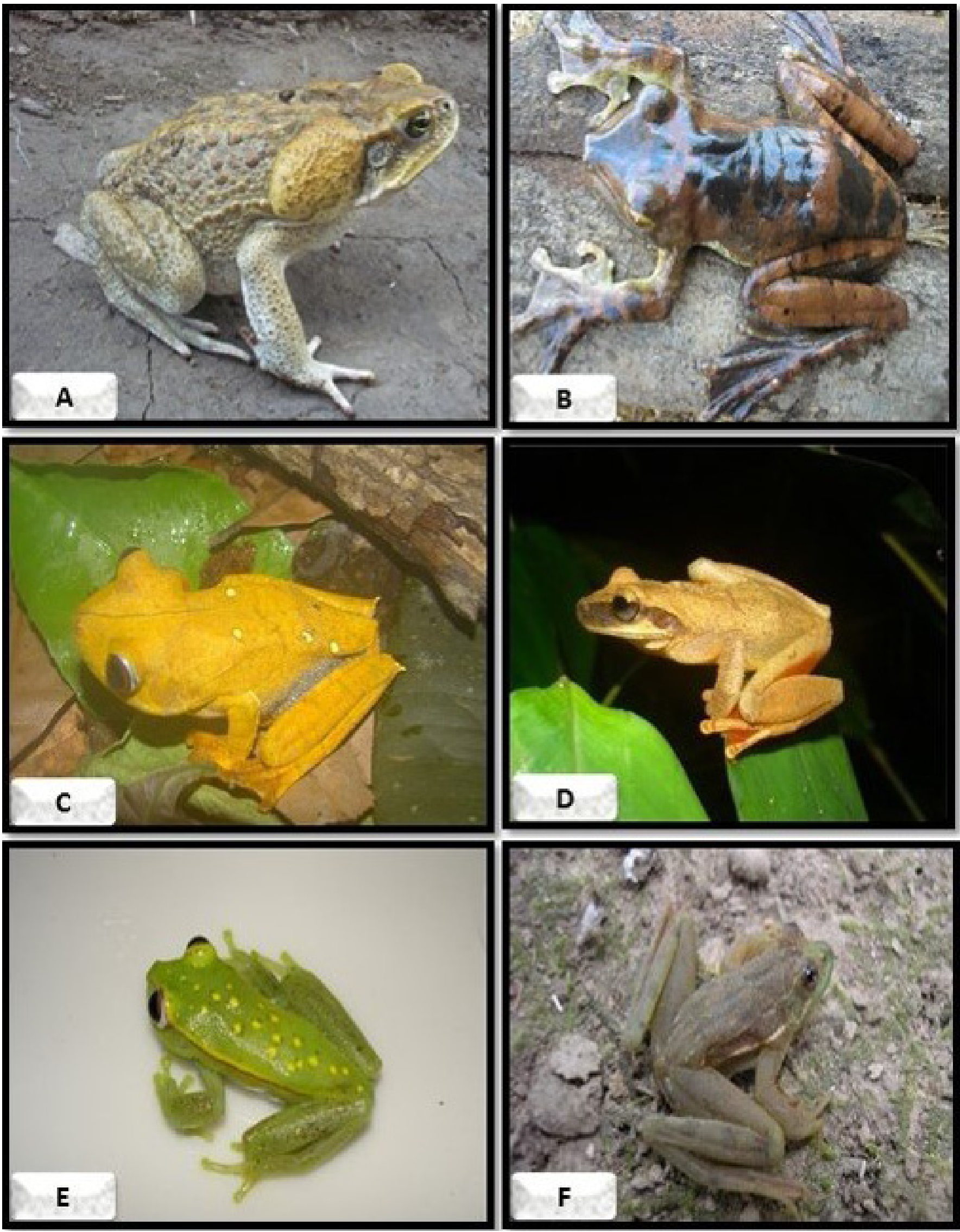

Figure 4. Anuran amphibians recorded in the Amazonian savanna of the Rio Curiaú Environmental Protection Area in Amapá, northern Brazil. A - Rhinella marina, B - Hypsiboas boans, C - Hypsiboas geographicus, D - Hypsiboas multifasciatus, E - Hypsiboas punctatus and F - Lysapsus boliviana. 

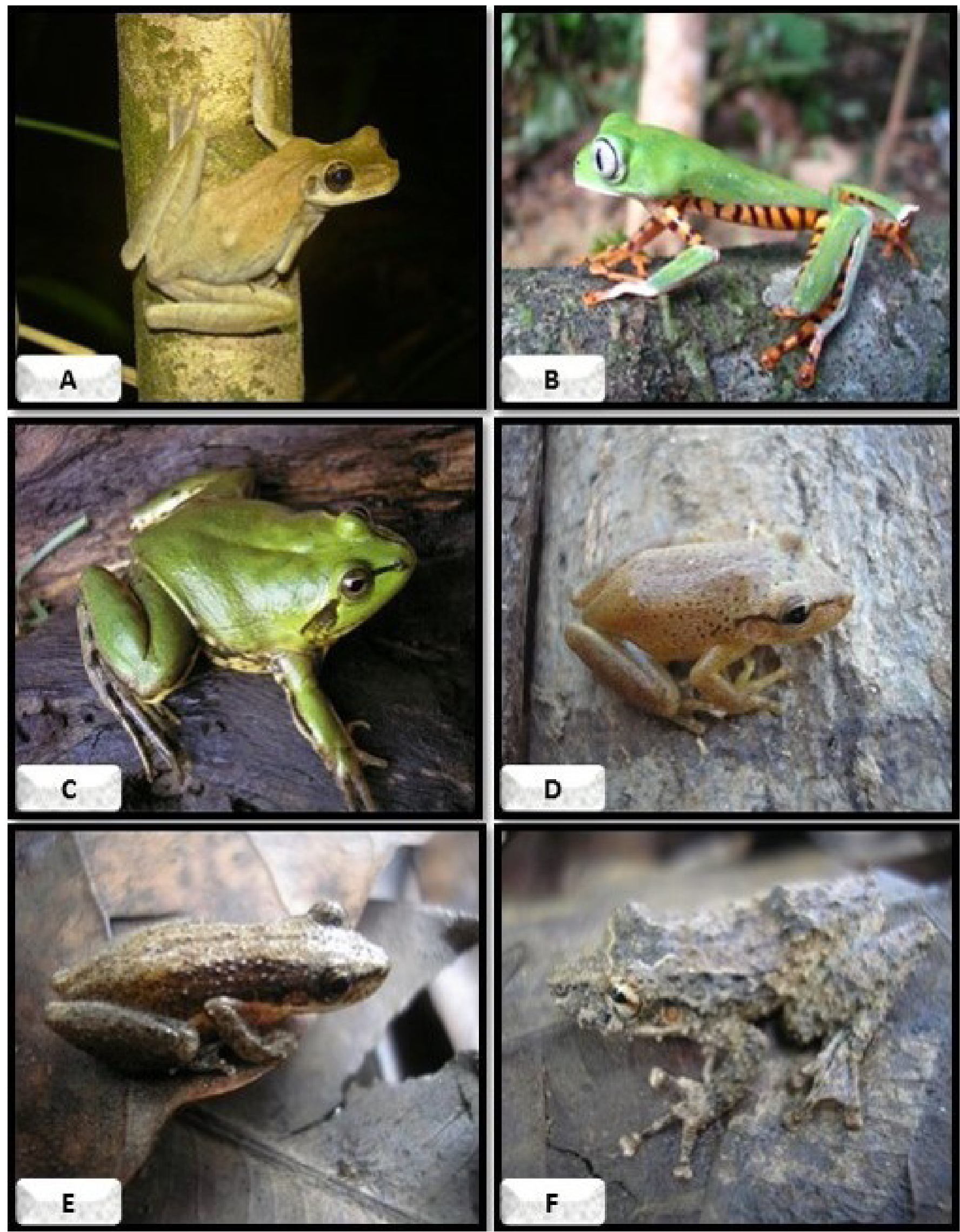

Figura 5. Anuran amphibians recorded in the Amazonian savanna of the Rio Curiaú Environmental Protection Area in Amapá, northern Brazil. A-Osteocephalus taurinus, B - Phyllomedusa hypochondrialis, C - Pseudis paradoxa, D -Scinax boesemani, E - Scinax fuscomarginatus and F -Scinax garbei. 

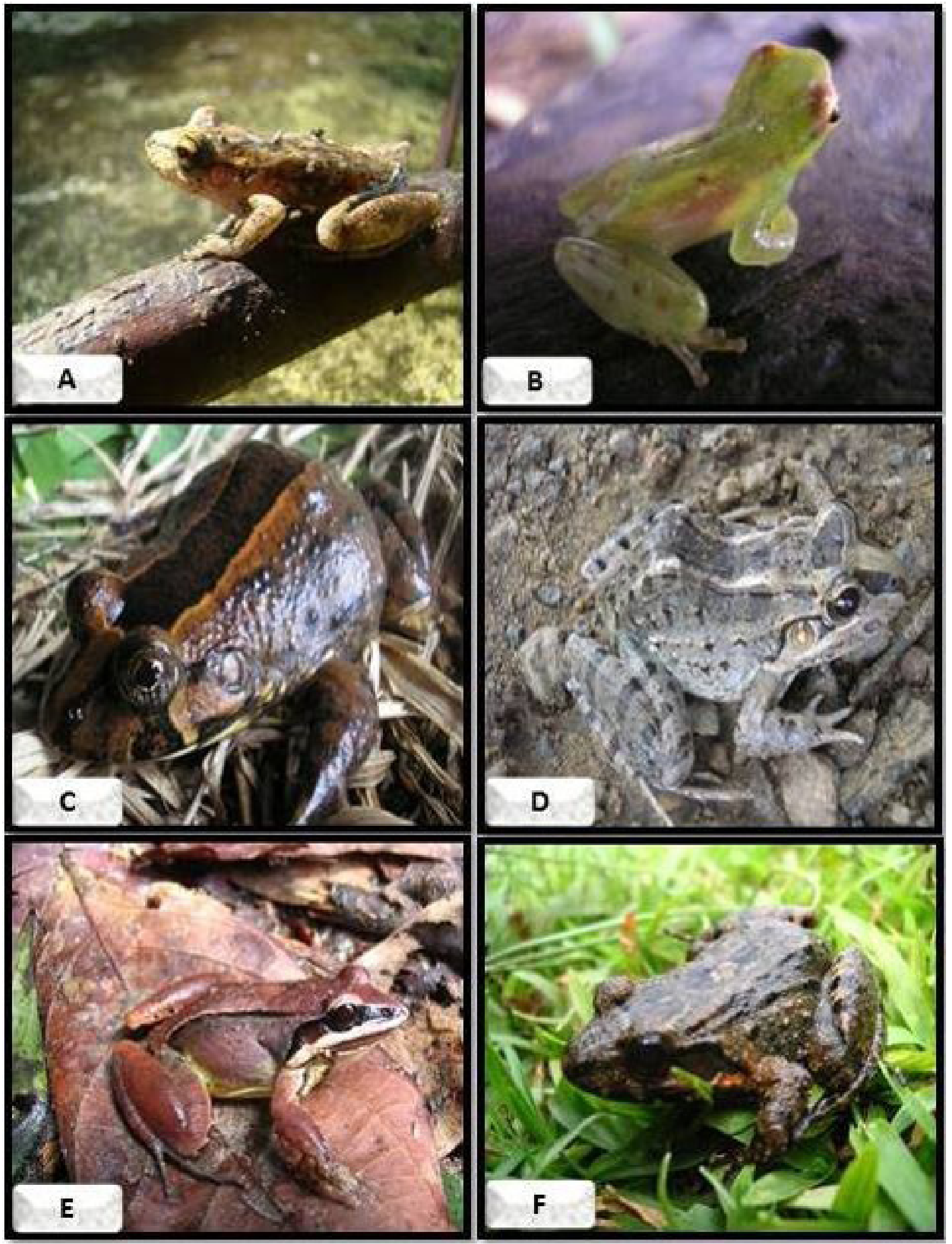

Figura 6. Anuran amphibians recorded in the Amazonian savanna of the Rio Curiaú Environmental Protection Area in Amapá, northern Brazil. A - Scinax ruber, B - Sphaenorhyncus carneus, C - Hydrolaetare schmidti, D - Leptodactylus fuscus, E - Leptodactylus mystaceus and F - Leptodactylus petersii. 


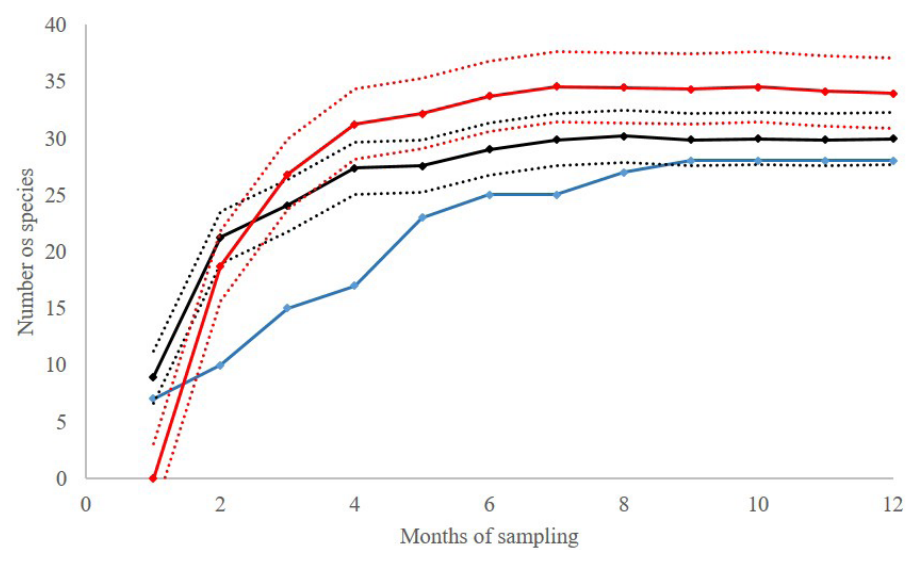

Figure 7. Cumulative and rarefaction curves to amphibian species recorded during 12 months of sampling in the Rio Curiaú Environmental Protection Area in Amapá, northern Brazil. Blue line represents accumulation curve, red line represents species estimates based on Jackknife 2 estimator, black line represents species estimates based on Chao 2; dashed lines represents the $95 \%$ confidence intervals.

the dense terra firme forests of the Tumucumaque Mountains National Park in northern Amapá, which is considered to be the world's largest park of continuous tropical forest, located on the Guiana Shield. Scinax garbei, Scinax boesemani and Sphaenorhyncus lacteus were also recorded by Waldez et al. (2013) in the region of the lower Purus River in the central Amazonian basin in a vast, continuous mosaic landscape of terra firme forests and várzea.

The fact that these species (Leptodactylus mystaceus, Leptodactylus petersii, Hypsiboas boans, Scinax boesemani, Scinax garbei, Hydrolaetare schmidit, Hamptophryne boliviana, and Sphaenorhyncus lacteus) have been recorded in forest habitats in other studies (Lima 2008, Menin et al. 2008, Avila-Pires et al. 2010, Waldez et al. 2013, Lima et al. 2015) suggests that their presence in the Rio Curiaú study area was due to the proximity of the ponds surveyed to the forest patches found in the local landscape. The phytophysiognomy of the study area in the Rio Curiaú EPA is composed mainly of savanna, with islands of savanna forest, and as some lakes are found in the vicinity of these forests, the anuran species composition may be enriched by this environment, due to the use of these pools by many forest-dwelling species that have aquatic larvae.

Recently, Doria et al. (2015) demonstrated the influence of variables associated with the presence of bodies of water on the distribution of anurans in the transition zone of the Brazilian Cerrado savanna and Caatinga dry forest. Further studies will be necessary to determine which variables favor the occupation of the savannas of the Rio Curiaú by forest-dwelling species.

In this case, it seems likely that amphibian species occurring in the várzea swamp forests found within the Rio Curiaú EPA used the nearby temporary ponds to breed, influencing the diversity of species encountered during the surveys. The mosaic of savanna, forest patches, swamps, and temporary ponds found within the Rio Curiaú EPA is thus extremely important for the maintenance of species, and the conservation of local amphibian diversity, given the occurrence in the ponds of species typical of the savanna, terra firme forest, and várzea swamps. Clearly, effective conservation measures for the EPA should focus primarily on the maintenance of this mosaic of environments, which favors the amphibian diversity of the study area.

Overall, the results of the present study provide important insights into the diversity of the amphibians of the Amazonian savanna, especially considering the scarcity of data for this environment, as highlighted by Azevedo-Ramos \& Galatti (2001). In particular, the record of Sphaenorhynchus carneus in the EPA (Figura 5A) represents a southward extension of the known distribution of the species in the savannas of Amapá. Despite being widely-distributed in the Amazon basin (Azevedo-Ramos et al. 2004), only a single record of this species exists from Amapá, from an area of savanna in the district of Ariri, Macapá (Correa et al. 2015), and these populations are currently isolated by paved highways and soybean plantations. The results of the present study thus provide important insights into the diversity of amphibians in the Guianan area of endemism in northern Brazil and the Amazonian savannas.

Appendix 1: Voucher specimens of amphibians collected in the Amazonian Savanna in the Environmental Protection Area of Rio Curiaú, Amapá, northern Brazil.

Rhinella granulosa-IEPA4002, IEPA4005; Rhinella marina-IEPA4003; Dendropsophus sp. - IEPA4004; Dendropsophus nanus - IEPA4010, IEPA4015; IEPA4017; Hypsiboas boans - IEPA4007; Hypsiboas geographicus - IEPA4009; Hypsiboas multifasciatus-IEPA4011, IEPA4012; Hypsiboas punctatus-IEPA4006, IEPA4008; Hypsiboas raniceps - IEPA4013; Lysapsus boliviana - IEPA4014, IEPA4016; Phyllomedusa hypochondrialis-IEPA4019; Osteocephalus taurinus -IEPA 4018; Scinax boesemani - IEPA4020, IEPA4021; Pseudis paradoxa - IEPA4035; Scinax fuscomarginatus - IEPA4029; Scinax garbei-IEPA4027, IEPA4030; Scinax nebulosus - IEPA4034, IEPA4025; Scinax ruber-IEPA4022, IEPA4026; Sphaenorhynchus carneus - IEPA4023; Sphaenorhynchus lacteus - IEPA4031; Hydrolaetare schmidti - IEPA4024; Leptodactylus fuscus - IEPA4031, IEPA4033; Leptodactylus longirostris -IEPA4032; Leptodactylus macrosternum -IEPA4042, IEPA4040; Leptodactylus mystaceus - IEPA4036, IEPA4037; Leptodactylus petersii-IEPA4038, IEPA4041; Pseudopaludicola sp. - IEPA4039, IEPA4044; Hamptophryne boliviana - IEPA4043.

\section{Acknowledgements}

J. R. F. L thanks CAPES for fellowships and Posgraduate program in Biodiversity and Biotechonoly - BIONORTE Network and Institute of Scientific and Technological Research of the State of Amapá - IEPA. G.V.A., J.R.F.L. and S. D. L thanks SISBIOTA Program (CNPq: 563075/2010-4 and Fapesp: 2010/52321-7). G.V.A. thanks the research fellowship of CNPq (Proc.:312286/2015-5). We are grateful to an anonymous reviewer for helpful comments on the original version of the manuscript.

\section{Authors Contributions}

Janaina Reis Ferreira Lima: substantial contribution in the concept and design of the study, contribution to data collection, contribution to data analysis and interpretation, contribution to manuscript preparation and contribution to critical revision, adding intelectual contente.

Jucivaldo Dias Lima: substantial contribution in the concept and design of the study, contribution to data collection, contribution to data analysis and interpretation, contribution to manuscript preparation and contribution to critical revision, adding intelectual contente.

Soraia Dias Lima: contribution to data collection and contribution to manuscript preparation.

Raullyan Borja Lima e Silva: substantial contribution in the concept and design of the study, contribution to data analysis and interpretation, contribution to manuscript preparation and contribution to critical revision, adding intelectual contente.

Gilda Vasconcellos de Andrade: substantial contribution in the concept and design of the study, contribution to data analysis and interpretation, contribution to manuscript preparation and contribution to critical revision, adding intelectual contente. 


\section{Conflicts of interest}

The authors declares that they have no conflict of interest related to the publication of this manuscript.

\section{References}

ARAÚJO, A.S. \& COSTA-CAMPOS, C. E. 2014. Anurans of the Reserva Biológica do Parazinho, Municipality of Macapá, state of Amapá, eastern Amazon. Check List 10: 1414-1419.

AVILA-PIRES, T.C.S., HOOGMOED, M.S., ROCHA, W.A. 2010. Notes on Vertebrates of Northern Pará, Brazil: a forgotten part of the Guianan Region, I. Herpetofauna. Bol. Mus. Para. Emílio Goeldi. Cien. Nat. Belém. 5(1): 13-112.

AZEVEDO-RAMOS, C. \& GALATTI, U. 2001. Patterns of Amphibian Diversity in Brazilian Amazonia: Conservation Implications. Biol. Conserv. 103(1):103-111.

AZEVEDO-RAMOS, C., COLOMA, L.A. \& SANTIAGO, R. 2004. Sphaenorhynchus carneus. The IUCN Red List of Threatened Species. Version 2014.3. Accessed at http://www.iucnredlist.org (last acess at 02/03/2016).

BARBOSA, R.I., CAMPOS, C., PINTO, F., FEARNSIDE, P.M. 2007. The "Lavrados" of Roraima. Biodiversity and Conservation of Brazil's Amazonian Savannas. Functional Ecosystens and Communities 1(1): 30-42.

BERNARDE, P.S. 2007. Ambientes e temporada de vocalização da anurofauna no Município de Espigão do Oeste, Rondônia, Sudoeste da Amazônia - Brasil (Amphibia: Anura). Biota Neotrop. 7(2): http: www.biotaneotropica.org.br/ v7n2/pt/abstract?article+bn01507022007 (last acess at 02/01/2016).

BERNARDE, P.S., MACHADO, R.A. \& TURCI, L.C.B. 2011. Herpetofauna da área do Igarapé Esperança na Reserva Extrativista Riozinho da Liberbade, Acre - Brasil. Biota Neotrop. 11(3): http://www.biotaneotropica.org.br/v11n3/ pt/abstract?article+bn02111032011 (last acess at 03/03/2016).

BITAR, Y.O.C., JUEN, L., PINHEIRO, L.P.C. \& SANTOS-COSTA, M.C. 2015. Anuran Beta Diversity in a Mosaic Anthropogenic Landscape in Transitional Amazon. J. Herpetol. 48: 75-82.

BRANDÃO, R.A., GARDA, A.A., BRAZ, V., FONSECA, B. 2003. Observation on the ecology of Pseudis bolbodactyla (Anura, Pseudidae) in central Brazil. Phyllomedusa 2: 3-8.

COSTA-CAMPOS, C.E. 2015. Ecologia de comunidade e comportamento reprodutivo de anfíbios anuros em Savana Amazônica. Tese de Doutorado. Universidade Federal do Rio Grande do Norte, RN.

COLE, C.J., TOWNSEND, C.R., REYNOLDS, R.P., MACCULLOCH, R.D. \& LATHROP, A. 2013. Amphibians and reptiles of Guyana, South America: illustrated keys, annotated species accounts, and a biogeographic synopsis. Proc. Biol. Soc. Wash. 125(4): 317-578.

CORRÊA, J.G., SOUSA, J.C., FRANÇA, P.F., COSTA-CAMPOS, C.E. 2015. First record of Sphaenorhyncus carneus in the eastern Amazon, Amapá state. Check List 11(4): 1725 .

COLWELL, R. K. 2013. EstimateS, version 9.1: Statistical estimation of species rechness and shared species from samples. http://viceroy.eeb.uconn.edu/estimates/ EstimateSPages/EstSUserGuide.htm (last acess at 02/02/2016).

DORIA, T.A.F., KLEIN, W., ABREU, R.O., SANTOS, D.C., CORDEIRO, M.C., SILVA, L.M., BONFIM, V.M., NAPOLI, M.F. 2015. Environmental Variables Influence the Composition of Frog Communities in Riparian and Semi-Deciduous Forests of the Brazilian Cerrado. South Am. J. Herpetol. 10(2): 90-103.

DUELLMAN, W.E. 1988. Pattern of species diversity in anuran amphibians in the American tropics. Ann. Missouri Bot. Gard. 75: 79-104.

FAHR, J. \& KALKO, E.K.V. 2011. Biome transitions as centres of diversity: habitat heterogeneity and diversity patterns of West African bat assemblages across spatial scales. Ecography 34: 177-195.

FURTADO, M.F.M., COSTA-CAMPOS, C.E., QUEIROZ, S.S., CORREA, K.J.G., VIEIRA, I.M. 2013. Ocorrência de Macrobrachium amazonicum (Crustacea; Decapoda) na dieta de Lysapsus bolivianus (Anura, Hylidae). Biota Amazônia. 3(3): 185-187.

FURTADO, M.F.M., COSTA-CAMPOS, C.E., QUEIROZ, S.S. 2014. Estrutura populacional e padrão reprodutivo de Pseudis boliviana (Gallardo, 1961) (Anura: Hylidae) emu ma planície de inundação na Amazônia Oriental. Biota Amazônia. 4(2): 68-73.
GONDIM-SILVA F.A.T., ANDRADE, A.R.S., ABREU, R.O., NASCIMENTO, J.S., CORRÊA, G.P., MENEZES, L., TREVISAN, C.C., CAMARGO, S.S., NAPOLI, M.F. 2016. Composition and diversity of anurans in the Restinga of the Conde municipality, northern coast of the state of Bahia, northeastern Brazil. 16(3): e20160157. http://dx.doi.org/10.1590/1676-0611-BN-2016-0157 (last acess at 02/10/2016).

GORDO, M. 2003. Os anfíbios anuros do Baixo Rio Purus/Solimões In: PiagaçuPurus: Bases científicas para a criação de uma Reserva de Desenvolvimento Sustentável, (C.P. Deus, R. Silveira \& L.H.R. Py-Daniel, eds). Manaus: Instituto de Desenvolvimento Sustentável Mamirauá. p. 243-256.

HEYER, W.R., DONNELLY, M.A., MCDIARMID, R.W., HAYEK.L.A.C. \& FOSTER, M.S. 1994. Measuring and Monitoring Biological Diversity: Standard Methods for Amphibians. Biological Diversity Handbook Series. Stmithsonian Intitution Press. Washington.

HOOGMOED, M.S. \& AVILA-PIRES, T.C.S. 1991. Annotated checklist of the herpetofauna of Petit Saunt, Sinnamary River, French Guiana. Zool Med. 65: 53-88.

HOOGMOED, M.S. 2016a. Censo da Biodiversidade da Amazônia Brasileira. Grupo: Caudata. http://www.museu-goeldi.br/censo (last acess at 22/07/2016).

HOOGMOED, M.S. 2016b. Censo da Biodiversidade da Amazônia Brasileira. Grupo: Gymnophiona. http://www.museu-goeldi.br/censo (last acess at 22/07/2016).

HOOGMOED, M.S. \& GALATTI, U. 2016. Censo da Biodiversidade da Amazônia Brasileira. Grupo: Anura. http://www.museu-goeldi.br/censo (last acess at 22/07/2016).

ILHA, P. \& DIXO, M. 2010. Anurans and Lizards, Rio Preto da Eva, Amazonas, Brazil. Check List 6(1): 17-21.

LESCURE, J. \& MARTY, C. 2000. Atlas des Amphibiens de Guyane. Collect. Patrim. Nat. 45: 1-388.

LIMA, J.D. 2008. A herpetofauna do Parque Nacional do Montanhas do Tumucumaque, Amapá, Brasil, Expedições I a V In: Inventários Biológicos Rápidos no Parque Nacional Montanhas do Tumucumaque, Amapá, Brasil, (E. Bernard, coord.). RAP Bulletin of Biological Assessment 48. Arlington: Conservation International. p. 38-50.

LIMA, A.P., MAGNUSSON, W.E., MENIN, M., ERDTMANN, L.K., RODRIGUES, D.J., KELLER, C. \& HÖDL, W. 2012. Guia de Sapos da Reserva Adolpho Ducke, Amazônia Central. 2nd edition. Manaus: Editora INPA. p. 187.

LIMA, J.R., GALATTI, U., LIMA, C.J., FAVERI, S.B., VASCONCELOS, H.L., NECKEL-OLIVEIRA, S. 2015. Amphibians on Amazonian Land-Bridge Islands are Affected More by Area Than Isolation. Biotropica 47(3): 369-376.

MACCULLOCH, R.D. \& REYNOLDS, R.P. 2012. Amphibians and reptiles from Paramakatoi and Kato, Guyana. Check List 8(2): 207-210.

MAGURRAN, A. E. 2004. Measuring Biological Diversity. Ed. Blackwell Publ.

MENIN M., WALDEZ, F. \& LIMA, A.P. 2008. Temporal variation in the abundance and number of species of anurans in 10,000 ha of a forest in Central Amazonia, Brazil. South Am J Herpetol. 3: 68-81.

NECKEL-OLIVEIRA, S. \& GORDO, M. 2004. Anfíbios, lagartos e serpentes do Parque Nacional do Jaú In: Janelas para a biodiversidade no Parque Nacional do Jaú - uma estratégia para o estudo da biodiversidade na Amazônia (S.H. Borges, S. Iwanaga, C.C. Durigan \& M.R. Pinheiro, eds.) Manaus: Fundação Vitória Amazônica. p. 161-176.

NECKEL-OLIVEIRA, S., MAGNUSSON, W.E., LIMA, A.P., ALBERNAZ, A.L.K. 2000. Diversity and distribution of frogs in an Amazonian savanna in Brazil. Amphibia-Reptilia. 21: 317-326.

PEEL M.C., FINLAYSON, B.L. \& MCMAHON, T.A. 2007. Updated world map of the Köppen-Geiger climate classification. Hydrol. Earth Syst. Sc. 4: 439-473.

PEREIRA-JÚNIOR, A.P., COSTA-CAMPOS, C.E. \& ARAÚJO, A.S. 2013. Composição e diversidade de anfíbios anuros do campus da Universidade Federal do Amapá. Biota Amazônia 3(1): 13-21.

PRUDENTE, A.L.C., STURARO, M.J., TRAVASSOS, A.E.M., MASCHIO, G.F. \& SANTOS-COSTA, M.C. 2013. Anurans of the Urucu Petrol Basin, municipality of Coari, State of Amazonas, northern Brazil. Check List 9(3): 601-606.

QUEIROZ, S.S., SILVA, A.R., REIS, F.M., LIMA, J.D. \& LIMA, J.R.F. 2011. Anfíbios de uma área de castanhal da Reserva Extrativista do Rio Cajari, Amapá. Biota Amazônia 1(1): 1-18. 
Lima, J.R.F. et al.

REYNOLDS, R.P. \& MACCULLOCH, R.D. 2012. Preliminary checklist of amphibians and reptiles from Baramita, Guyana. Check List 8(2): 211-214.

RIBEIRO-JÚNIOR, M.A., GARDNER, T.A. \& AVILA-PIRES, T.C.S. 2008. Evaluating the effectiveness of herpetofaunal sampling techniques across a gradient of habitat change in a tropical forest landscape. J. Herpetol. 42: 733-749.

ROCHA, A.E.S., MIRANDA, I.S. \& COSTA NETO, S.V. 2014. Composição florística e chave de identificação das Poaceae ocorrentes nas savanas costeiras amazônicas, Brasil. Acta Amaz. 44(3): 301-314

SEGALLA, M.V., CARAMASCHI, U., CRUZ, C.A.G., GRANT, T., HADDAD, C.F.B., GARCIA, P.C.A., BERNECK, B.V.M., LANGONE, J. A. 2016. Brazilian amphibians: List of species. Herpetologia Brasileira, 5(2): 34-46.

SEMA (Secretaria Estadual do Meio Ambiente). Relatório: Gestão participativa da APA do Curiaú, 2003. p. 35.

SILVA, J.M.C., RYLANDS, A.B., FONSECA, G.A.B. 2005. O destino das áreas de endemismo da Amazônia. Megadiversidade. 1(1): 124-131.

SILVA, R.B.L., FREITAS, J.L., SANTOS, J.U.M., SOUTO, R.N.P. 2013. Caracterização agroecológica e socioeconômica dos moradores da comunidade quilombola do Curiaú, Macapá - AP, Brasil. Biota Amazônia. 3 (3): 113-138.

SOUZA, A. \& ETEROVICK, P. 2011. Environmental factors related to anuran assemblage composition, richness and distribution at four large rivers under varied impact levels in southeastern Brazil. River res. Appl. 27: 1023-1036.

STRUSSMANN, C. 2000. Herpetofauna In:Fauna Silvestre da região do Rio MansoMato Grosso. Edições IBAMA. Mato Grosso. p. 153-189.

SUGAI, J.L.M.M., TERRA, J.S. \& FERREIRA, V.L. 2014. Anurans of a threatened savanna area in western Brazil. Biota Neotrop. 14 (1): http://www.biotaneotropica. org.br/v14n1/pt/abstract?inventory+bn0021404058 (last acess at 02/03/2016).
TOCHER, M.D., GASCON, C. \& MAYER, J. 2001. Community composition and breeding success of Amazonian anurans in continuous forest and matrix habitat aquatic sites In: Lessons from Amazonia: The ecology and conservation of a fragmented forest (R.O. Bierregaard, JR.C. Gascon, T.E. Lovejoy \& R. Mesquita, eds.). New Haven: Yale University Press. p. 235-247.

TURCI, L.C.B. \& BERNARDE, P.S. 2008. Levantamento herpetofaunístico em uma localidade no município de Cacoal, Rondônia, Brasil. Bioikos 22: 101-108.

VOGT, R.C., FERRARA, C.R., BERNHARD, R., CARVALHO, V.T., BALENSIEFER, D.C., BONORA, L. \& NOVELE, S.M.H. 2007. Herpetofauna In: Biodiversidade do Médio Madeira: Bases científicas para propostas de conservação (L.R. Py-Daniel, C.P. Deus, A.L. Henriques, D.M. Pimpão, \& O.M. Ribeiro, eds.). Manaus: INPA. p. 127-143.

WALDEZ, F., MENIN, M. \& VOGT, V. 2013. Diversidade de anfíbios e répteis Squamata na região do baixo rio Purus, Amazônia Central, Brasil. Biota Neotrop. 13(1): http://www.biotaneotropica.org.br/v13n1/en/abstracr?invent ory+bn03113012013 (last acess at 02/01/2016).

ZIMMERMAN, B. L. \& RODRIGUES, M.T. 1990. Frogs, snakes, and lizards or the INPA-WWF reserves near Manaus, Brazil In: Four Neotropical Rainforest (A.H. Gentry, coord.). New Haven: Yale University Press. p. 426-454.

Received: 18/08/2016

Revised: 06/03/2017

Accepted: 07/03/2017

Published online: 27/03/2017 